\title{
JOTSE'S NEW CHALLENGES AND CONTINUOUS IMPROVEMENT
}

\author{
Beatriz Amante García ${ }^{1}$ (D), María Martínez Martínez ${ }^{2}$ (D) \\ ${ }^{1}$ Projectes d'Enginyeria, Universitat Politècnica de Catalunya (Spain) \\ ${ }^{2}$ Enginyeria Química, Universitat Politècnica de Catalunya (Spain) \\ beatrizamante@upc.edu,rosario.martinez@upc.edu
}

As usual in JOTSE, the first editorial of the year presents an analysis of our Journal evolution. In this sense, we reflect on the changes just undergone and the challenges to be faced in the New Year 2020.

As we can observe in Figure 1, the objective of steady growth has been accomplished throughout these 10 last years.

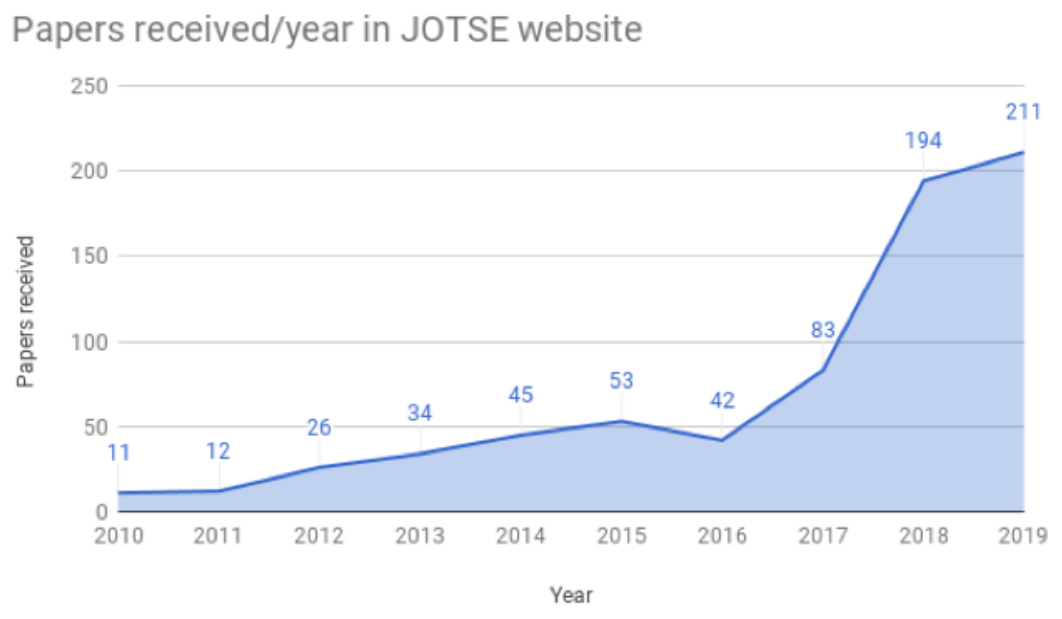

Figure 1. JOTSE's evolution

As a matter of fact, if we observe JOTSE's monthly evolution we can state that January, March, September and October are the months with more papers submissions as the average increases (as shown in Table 1) In particular, in year 2019 we have had $8 \%$ as much articles than in preceding year. In addition, JOTSE has been increase the indexation in SCOPUS to Q3 in 2018. It was a very good news for us and for ours authors.

As to the articles published (included in Table 2), we can observe the evolution of the volumes/issues and articles published in the years (2011-2019). In 2019, we have increased a little bit the number of articles published regularly and we have kept the number of paper published in special issues. When analysing the percentage of rejected articles we can see that in year 2016 it was $36 \%$, in 2017 the figure rose up to $69 \%$, in 2018 it was $64 \%$ and in 2019 it was 63\%. It is important to mention here the role of JOTSE's editorial team and reviewers who do their job with much rigor and out of their generosity. In fact, we could not publish our journal without their help and, therefore, we thank them all for this here. 


\begin{tabular}{|c|c|c|c|c|c|c|c|c|c|c|}
\hline & $\mathbf{2 0 1 0}$ & $\mathbf{2 0 1 1}$ & $\mathbf{2 0 1 2}$ & $\mathbf{2 0 1 3}$ & $\mathbf{2 0 1 4}$ & $\mathbf{2 0 1 5}$ & $\mathbf{2 0 1 6}$ & $\mathbf{2 0 1 7}$ & $\mathbf{2 0 1 8}$ & $\mathbf{2 0 1 9}$ \\
\hline January & & 0 & 2 & 1 & 9 & 4 & 3 & 2 & 12 & 26 \\
\hline February & & 1 & 4 & 1 & 0 & 4 & 1 & 7 & 27 & 15 \\
\hline March & & 0 & 1 & 2 & 3 & 5 & 1 & 4 & 11 & 27 \\
\hline April & 1 & 1 & 0 & 3 & 2 & 2 & 2 & 0 & 10 & 12 \\
\hline May & 3 & 2 & 0 & 0 & 2 & 2 & 3 & 5 & 24 & 13 \\
\hline June & 1 & 4 & 0 & 3 & 1 & 4 & 3 & 3 & 11 & 8 \\
\hline July & 1 & 0 & 7 & 5 & 8 & 5 & 3 & 2 & 13 & 15 \\
\hline August & 1 & 1 & 1 & 2 & 1 & 2 & 2 & 13 & 9 & 12 \\
\hline September & 0 & 1 & 3 & 1 & 5 & 5 & 2 & 14 & 32 & 24 \\
\hline October & 2 & 0 & 4 & 1 & 1 & 3 & 8 & 8 & 8 & 25 \\
\hline November & 1 & 1 & 1 & 6 & 2 & 9 & 11 & 11 & 16 & 14 \\
\hline December & 1 & 1 & 3 & 9 & 11 & 8 & 3 & 14 & 21 & 20 \\
\hline TOTAL & $\mathbf{1 1}$ & $\mathbf{1 2}$ & $\mathbf{2 6}$ & $\mathbf{3 4}$ & $\mathbf{4 5}$ & $\mathbf{5 3}$ & $\mathbf{4 2}$ & $\mathbf{8 3}$ & $\mathbf{1 9 4}$ & $\mathbf{2 1 1}$ \\
\hline
\end{tabular}

Table 1. Article submissions evolution from 2010 to 2019

\begin{tabular}{|l|l|c|c|c|}
\hline & Issues & $\begin{array}{c}\text { Articles published in } \\
\text { regular issue }\end{array}$ & $\begin{array}{c}\text { Articles published in } \\
\text { special issue }\end{array}$ & $\begin{array}{c}\text { Total } \\
\text { papers }\end{array}$ \\
\hline $\mathbf{2 0 1 1}$ & $2(2+0)$ & 11 & 0 & 11 \\
\hline $\mathbf{2 0 1 2}$ & $2(2+0)$ & 12 & 0 & 12 \\
\hline $\mathbf{2 0 1 3}$ & $3(2+1)$ & 11 & 7 & 18 \\
\hline $\mathbf{2 0 1 4}$ & $4(2+2)$ & 12 & 14 & 26 \\
\hline $\mathbf{2 0 1 5}$ & $4(2+2)$ & 10 & 15 & 25 \\
\hline $\mathbf{2 0 1 6}$ & $3(2+1)$ & 13 & 6 & 19 \\
\hline $\mathbf{2 0 1 7}$ & $3(2+1)$ & 10 & 11 & 21 \\
\hline $\mathbf{2 0 1 8}$ & $4(2+2)$ & 26 & 10 & 36 \\
\hline $\mathbf{2 0 1 9}$ & $3(2+1)$ & 29 & 11 & 40 \\
\hline
\end{tabular}

Table 2. Articles published evolution from 2010 to 2019

In this vein, if we analyses JOTSE's internationalisation as to visits to its website is concerned (one of our challenges). The countries that have visited JOTSE's website more frequently in the last years and more particularly in 2019 was:

-Philippines the first position with $24 \%$ of visited JOTSE's website

-United States was second with $16.3 \%$

-Spain in the third position with $9.41 \%$.

This is a clear evidence that the degree of internationalisation of JOTSE Journal is increasing. At the moment we have more articles from foreign countries (21 last year) and not so many from Spain (only $12 \%)$.

Finally, we repeat the importance of the reviewers and the JOTSE's editorial team without their help we could not publish at all this journal.

To conclude, the new objectives is to continue extending and reaching more countries, growing moderately and with quality. 
Last but not least, we would like to thank PhD Juan Antonio Llorens, from the Polytechnic University of Valencia (UPV) for his job and teamwork within the Editorial team in the last few years and we wish him great success in the new stage. Finally, we would like to thank to readers and authors for continuing to trust us.

\section{Declaration of Conflicting Interests}

The authors declared no potential conflicts of interest with respect to the research, authorship, and/or publication of this article.

\section{Funding}

The authors received no financial support for the research, authorship, and/or publication of this article.

\section{To cite this article:}

Amante García, B., \& Martínez Martínez, M (2020). JOTSE's new challenges and continuous improvement. Journal of Technology and Science Education, 10(1), 1-3.

https://doi.org/10.3926/jotse.944

Published by OmniaScience (www.omniascience.com)

Journal of Technology and Science Education, 2020 (www.jotse.org)

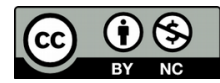

Article's contents are provided on an Attribution-Non Commercial 4.0 Creative commons International License. Readers are allowed to copy, distribute and communicate article's contents, provided the author's and JOTSE journal's names are included. It must not be used for commercial purposes. To see the complete licence contents, please visit https://creativecommons.org/licenses/by-nc/4.0/. 